\title{
Yazın çevirisi incelemelerinde yorumlayıcı çeviri kuramı ${ }^{1}$
}

\section{Onur ÖZCAN²}

APA: Özcan, O. (2019). Yazın çevirisi incelemelerinde yorumlayıcı çeviri kuramı. RumeliDE Dil ve Edebiyat Araştırmaları Dergisi, (16), 587-603. DOI: 10.29000/rumelide.619082

\section{$\ddot{\mathbf{O} z}$}

XX. yüzyılda başlayan çeviri alanındaki araştırmalar, yerini giderek çevirinin bilimselleşme yolunda kat ettiği çalışmalara bırakmıştır. Bu çalışmaların başında belirli bir alana kazandırılan çevirilerin, çeviribilimin gücünün ve bağımsızlı̆̆ının temeli olan çeviri kuramları çerçevesinde incelenmeleri gelmektedir. Daha çok XXI. yüzyılda karşılaşılan bu tür incelemelerin odağını yazılı çeviriler oluşturmaktadır. Bu çeviri incelemelerine en iyi örnekler sunabilecek alan, yazın çevirisidir. Farklı dil kullanımlarına sahip türler içeren yazın çevirisi alanı, uluslararası ve yazınlararası bir görev üstlenmektedir. Bu yüzden, bu alanda yapılacak çeviriler diğer çeviri alanları kadar önemli olmakla birlikte, bir ülke yazınının çeviri yoluyla hem gelişmesinde hem de yaylmasında önemli bir rol oynamaktadır. Böylece çeviri kuramları çerçevesinde yazın alanında yapılan çevirileri incelemek, bu alanda çalışmalar yapan araştırmacılara ve yetişen çevirmen adaylarına ışık tutacağı gibi, yazarların eserlerinin doğru çeviri süreçlerinden geçerek hedef dilde kontrollü bir şekilde yer almasını sağlayacaktır. Burada, çeviri çalışmalarında kuramların önemi ortaya çıkmaktadır. Bu kuramlardan biri de Yorumlayıcı Çeviri Kuramı’dır. Yazın çevirisi incelemelerinde arka planda kaldığı düşünülen ve merkezine çevirmenin kararlarını alan bu kuramın çeviri sürecini ele alışı dikkat çekmektedir. Çeviri sürecini, çeviride eşdeğerlik ve uygunluk ilkesiyle birlikte anlam, anlama, sözcüklerden sıyırma ve yeniden ifade etme aşamalarına dayandırır. Çalışmamızda, Yorumlayıcı Çeviri Kuramı'nın çeviri sürecini oluşturan bu aşamaları, Fransızcadan Türkçeye birden fazla çevrilmiş roman, tiyatro, öykü ve şiir gibi farklı dil özelliklerine sahip yazın türlerinden karşılaştırmalı örneklerle çevirmenlerin kararları incelenecektir. Bu incelemeyle, Yorumlayıcı Çeviri Kuramı'nın çeviri süreçlerini uygulamalı ve karşılaştırmalı göstermek, yazın çevirisi sürecindeki çevirmen kararlarına dikkat çekmek ve kuramsal çeviri incelemeleri alanına katkı sağlamak amaçlanmaktadır.

Anahtar kelimeler: Çeviri incelemesi, yazın çevirisi, yorumlayıcı çeviri kuramı, çeviribilim, yazın çevirmeni.

\section{The interpretive theory of translation in analysis of literary translation}

\begin{abstract}
Researches in the field of translation, which began in the 2oth century, have gradually replaced the studies on the path to scientificization of translation. At the beginning of these studies, the analysis of the translations in a specific area, especially within the framework of translation theories which are the basis of the power and independence of translation studies are the leading. In XXI. century, the focus of such studies is written translations, that can provide best examples of translation analysis. The field of literary translation, which includes genres with different language uses, is taking
\end{abstract}

Bu makale, 12-13 Nisan 2019 tarihinde Kurklareli Üniversitesinde düzenlenen 2. Uluslararası Rumeli [Dil, Edebiyat, Çeviri] Sempozyumu'nda tebliğ olarak sunulmuştur.

2 Dr. Öğr. Üyesi, Kırıkkale Üniversitesi Fen Edebiyat Fakültesi Batı Dilleri ve Edebiyatları Bölümü Fransızca Mütercim Tercümanlık Anabilim Dalı (Kırıkkale, Türkiye), onurozcans@hotmail.com, ORCID ID: oooo-0002-4965-1627 [Makale kayıt tarihi: 21.08.2019-kabul tarihi: 20.09.2019; DOI: 10.29000/rumelide.619082] 
an international and interliterary role. Therefore, although the translations in this field are as important as other translation fields, they play an important role in the development and dissemination of a country literary through translation. Thus, in the frame of translation theories, analyzing the translations in the literary field will shed light on the researchers and the translator candidates who are working in this field, and will ensure that the literary works of authors pass through the correct translation processes in a controlled manner in the target language. Here, the importance of theories in translation studies emerges. One of these theories is the Interpretive Theory of Translation. This theory, being a secondary importance in the analysis of literary translation and putting the decisions of translator at the center of translation operation, is marked of its approaches to translation processes. It bases the translation process on the stages of meaning, comprehension, deverbalization and re-expression along with the principle of equivalence and correspondence in translation. In this study, the stages of the Interpretive Theory of Translation will be analyzed with the translations from French to Turkish of literary genres such as novels, theater, stories and poems. With this analyze, it is aimed to show the translation processes of the Interpretive Theory of Translation with practical and comparative examples, to draw attention to the translator decisions in the translation process and to contribute to the field of theoretical translation studies.

Keywords: Translation analysis, literary translation, the interpretive theory of translation, translation studies, literary translator.

\section{Giriş}

XXI. yüzyılda çeviribilim alanındaki çalışmalar giderek artmaktadır. Artan bu çalışmalar, çeviribilimin bilimselliğini kuvvetlendirmekle birlikte yapılan araştırma alanlarını da genişletmektedir. Sözel çevirilerden daha çok yazılı çeviriler bu çalışmaların ve çalışma alanlarının merkezini oluşturmaktadır. Çeviribilim alanına en çok örneklem sunabilecek alan olmasının yanı sıra akla ilk gelecek yazılı çeviri alanı yazın çevirisidir. Farklı dil özelliklerine sahip olan yazın, yapılan çalışmaların çeşitliliğinde önemli rol oynamaktadır. Özellikle çeviri incelemelerinde bu rolünün önemi ortaya çımaktadır.

Çeviribilim çatısı altında yapılan yazın çevirisi çalışmalarında, yazar, eser, dönem ve yazarın bağlı olduğu yazın akımı gibi konuların, özellikle salt çeviri incelemeleri çalışmalarında yapılan yorumların ya da eleştirilerin dışında kaldığı gözlemlenmektedir. Aynı zamanda bu tür çalışmaların herhangi bir çeviribilim kuramına veya kuramsal ölçütlere dayandırılmaması da dikkat çeken konulardan birisidir. $\mathrm{Bu}$ düşünceden, her çeviri inceleme çalışmasının bir kurama dayandırılma zorunluluğu anlamı çıkmamalıdır. Fakat çeviribilimin bilimselliği söz konusu ise, yapılan incelemelerde kuramsal ölçütlere başvurmanın alanı daha da güçlendireceği gibi özerkliğini de arttıracağı düşünülmektedir.

Roman, tiyatro, öykü ve şiir gibi yazın türlerinin çevirilerinin incelemelerini temel alan bu çalışmada, çeviri incelemelerinde kuramsal olarak fazla başvurulmayan Yorumlayıcı Çeviri Kuramı ele alınacaktır. Bu kurama ve söz konusu yazın türleri çevirileriyle ilgili başlıklara geçmeden önce, çeviri kuramları çerçevesinde çeviri incelemelerinin neden yapıldığına bir sonraki başlıkta değinmenin bu çalışmanın ve sonraki çalışmaların daha iyi anlaşılmasını sağlayacağı düşünülmektedir.

\section{2. Çeviri incelemeleri}

İster kuramsal ister salt çeviri çalışmalarında olsun çeviri incelemeleri, ortaya sürülen savları kuvvetlendirmede veya zayıflatmada sunduğu karşılaştırmalı örneklemler sayesinde çeviribilim 
çalışmalarının temel uygulaması olmaya devam etmektedir. Bu incelemeler, çeviri süreçlerinin farklı bakış açılarıyla ele alınmasında ve eşdeğer bir hedef metne ulaşılmasında çevirmenler ve araştırmacılar açısından vazgeçilmez bir çeviri çalışma modeli oluşturmaktadır. Çeviribilim alanının sürekliliğini destekleyecek bu çalışma modeli, gelecek çalışmaların ve ortaya çıkacak yeni yöntem ve kuramlar için fikir verici özelliğiyle ön planda olmayı sürdürmektedir. Fakat böylesine temel bir çalışma modeli olan çeviri incelemelerine neden başvurulduğuyla ilgili soru işaretleri mevcuttur. Bu yüzden genel olarak çeviri incelemelerinin ve bu incelemelerde bir kurama danışılmasının nedenleri aşağıda Tablo 1'de siralanmaktadır.

\begin{tabular}{|c|c|}
\hline Neden & Neden çeviri kuramına göre? \\
\hline $\begin{array}{l}\text {-Genel olarak çevirmen kararlarına ve çeviri } \\
\text { süreçlerine dikkat çekmek, } \\
\text {-Bu kararları ve süreçleri karşılaştırmak, } \\
\text {-Yapılan çevirinin ilgili alana göre uygunluğunu } \\
\text { (kaynak metne bağlılı̆̆ını) ve eşdeğerliğini tartışmak, } \\
\text {-Çeviribilim ve Mütercim-Tercümanlık bölümlerinde } \\
\text { yetişen çevirmen adaylarına yazılı ya da sözlü } \\
\text { simülasyon ortamı yaratmak ve mesleki } \\
\text { hazırbulunuşluk sağlamak, } \\
\text {-Çevirmenlerin hem kendi çevirileri hem de diğer } \\
\text { meslektaşlarının çevirileri hakkında farkındalık } \\
\text { yaratmak. }\end{array}$ & $\begin{array}{l}\text {-Genel olarak çevirmen kararlarına ve çeviri } \\
\text { süreçlerine bilimsel olarak dikkat çekmek, } \\
\text {-Bu kararları ve süreçleri ilgili kuramın çeviri sürecini } \\
\text { ele alış yöntemine göre karşılaştırmak, } \\
\text {-Uygunluk ve eşdeğerliği kuramsal olarak tartışmak, } \\
\text {-Çevirmen adaylarına gerçekten bilimsel bir alan ile } \\
\text { ilgilendiklerini ve bu alanın bilimsel yanı için halen bir } \\
\text { şeyler yapabileceklerinin/katkıda bulunabileceklerinin } \\
\text { farkına varmalarını sağlamak, } \\
\text {-Çevirmenlerin hem yaptığı ve yapacağı çeviriler hem } \\
\text { de meslektaşlarının çevirileri hakkında kuramsal } \\
\text { farkındalık yaratmak. }\end{array}$ \\
\hline
\end{tabular}

Tablo 1. Çeviri incelemelerinin nedenleri

Tablo 1, çeviri incelemelerinin genel nedenlerini ele almaktadır. Bu nedenlere üniversitelerin mütercimtercümanlı ve çeviribilim bölümlerindeki deneyimlerimizden ve çevirmenlerle olan görüşmelerimizden yola çıkarak ulaşılmıştır. Aynı zamanda bu nedenler, ana nedenler olarak adlandırılabilir. Çünkü bu nedenlerden başka birçok neden daha sıralanabilir. Çalışmanın çıkış noktası yazın çevirisi olduğundan, çeviri incelemelerinin yazınlararası gibi bir görevi olduğundan, bir ulusun yazınının diğer bir ulusla kaynaşmasındaki rolü; yazarın hedef kültür ve yazınında daha iyi anlaşılmasında ve yazara özgü özelliklerin eşdeğer bir şekilde daha dikkatlice aktarılmasındaki rolü diğer nedenler olarak örnek gösterilebilir.

Aslında genel olarak bu tabloda, salt çeviri incelemesinin önemine "Neden Çeviri İncelemesi” başlığında değinilse de, "Neden Çeviri Kuramına Göre" başlı̆̆ında çeviribilimin bilimsel gücünün dayanaklarından olan çeviri kuramlarının ve bu kuramlara göre yapılan incelemelerin ne derece önemli olduğunun da altı çizilmektedir.

Bu savları uygulamada daha iyi gözlemlemek için, çalışmanın fikrinin çıkış noktalarından biri olan Yorumlayıcı Çeviri Kuramı ve bu kuramın çeviri süreci aşamaları bir sonraki başlıkta ele alınacaktır.

\section{Yorumlayıcı çeviri kuramı (La théorie interprétative de la traduction)}

XX. yüzyılın ikinci yarısında çeviribilim alanında devam eden kuramsal çalışmalara, Paris 3 Sorbonne Üniversitesi Mütercim-Tercümanlık Okulu (l’École Supérieure d'Interprètes et de Traducteurs-ÉSIT) çatısı altında ortaya çıkan Danica Seleskovitch ve Marianne Lederer'in kurucusu olduğu bugün anlam kuramı (la téorie du sens) olarak da bilinen Yorumlayıcı Çeviri Kuramı (YÇK) eklenmiştir. YÇK, çeviri sürecinin "kaynak metnin anlaşılmasından, dilbilimsel biçiminin sözcüklerden sıyrılmasından ve anlaşılan düşünceleri ve hissedilen duyguları diğer bir dilde ifade etmekten ibaret olduğunu" (Lederer, 
1994, s.11) savunur. Kuramın savunduğu bu hipotez, aynı zamanda YÇK’nin temel yapısını oluşturur. Anlama (compréhension), sözcüklerden siyrılma (déverbalisation) ve yeniden ifade etme (réexpression) olarak üç ana başlıkta toplanır. Bu yapıyı oluşturan kavramlara bakıldığında, iletilmek istenen mesajın doğru yorumlanmasının gerektiğini ve mesajın anlamının önemli olduğunu, bu yüzden bu süreci yürütebilecek bir ögenin önemi ortaya çıkmaktadır. O da, çevirmendir.

Çevirmen, sisteminin merkezindedir (Laplace, 2005, s.34). YÇK, çevirmen merkezli bir kuram olup, çevirmenin kendi hayatını oluşturan tüm kültürel ve sosyal etmenlerin yanı sıra aldı̆̆ çeviri eğitimindeki bilimsel yaklaşımlarının ve sahip olduğu bilişsel bilgi dağarcığının bir araya gelmesinden oluşan bir kimliğe sahip olması gerekmektedir. Ayrıca, bu kuramın öncül fikirlerini sunan Edmond Cary'nin çeviri tanımında geçen "...farklı dillerde ifade edilen iki metin arasındaki eşdeğerlik..." (Lederer, 1994, s.11) ilkesi YÇK'da da hakim bir kavramdır. Bu eşdeğerlik kaynak metne biçemsel olarak yakınlığ ifade ederse, her kuramda olduğu gibi YÇK'da da uygunluğu temsil etmektedir.

O halde, merkezine çevirmeninin kararlarını alan YÇK, çeviride eşdeğerlik ve uygunluk ilkelerini benimsediğini ve çeviri sürecini anlam, anlama, sözcüklerden sıyırma ve yeniden ifade etme aşamalarına dayandırdığı düşünülmektedir.

\subsection{Anlam}

YÇK’nın asıl çıkış noktası anlamdır. Anlam çatısı altında, çeviri sürecindeki YÇK’nın yöntemi ortaya çımmaktadır. Lederer (1994) anlamın tanımını şu şekilde yapar:

Anlam, metin ya da konuşmanın bir parçasının uygun dilbilimsel ifadelerin ve bilişsel tamamlayıcıların oluşturduğu sentezin ürünüdür. Dilsel bilginin ve bilişsel tamamlayıcılarının birleştiği zamanda ki ses ya da yazı zincirinin sözcüklerinden sıyrılma sonucu oluşur. Hem bilişsel hem de duygusal olan anlam, bilinç haline uygundur (s.215).

Bu yüzden, YÇK'da metni ya da konuşmayı oluşturan sözcüklerin anlamını doğrudan anlamak yerine, metni ve konuşmayı bir bütün olarak anlamaya çalışmak ilke edinilmektedir. O yüzden, çevirmen kendini yazarın yerine koymayı çalışmalı ve istemelidir. Delisle, çeviribilimin, yazın çevirisini yeni anlamların üreticisi olarak görmesiyle birlikte, çevirmenlerin artık bir yazar kadar önem kazandığını, çoğu zaman çevrilen metnin yazarı olarak görüldüğünü belirtmektedir (2005, s.220). O halde anlam, aynı zamanda "bir yazarın ne söylemek istediği, söyledikleri arasında anlaşılır olması isteğidir" (age, s.35).

\subsection{Anlama}

Anlama, "anlam"dan ayrılmaz bir kavramdır. Anlam, dilbilimsel ve bilişsel bir sürecin sentezinin ürünü olarak ifade edilirken, anlama ise anlamda geçerli olan bu senteze ek olarak, çeviri işleminde çevirmenin dil dışı ve evrensel bilgi seviyesinin de önemine dikkat çekmektedir. Lederer'e göre "bir metni anlamak, dilsel beceriye ve aynı anda evrensel bilgi seviyesine başvurmaktır" (1994, s.32). Bu ifadesiyle Lederer anlama evresinin çevirmende nasıl gerçekleşeceği konusuna açıklık getirir ve anlamayı da şöyle tanımlar: "Bir dili anlamak, bir anlatımdaki kuralları ve sözcükleri tanımaktır... Bir metni ya da konuşmayı anlama, dilsel ifadenin ve bilişsel tamamlayıcıların bir araya gelmesiyle, bir ses ya da yazı zincirin anlamını ortaya çıaran bir süreçtir” (s.212).

O halde anlama, YÇK’nın işleme sürecindeki en önemli aşama olduğu düşünülmektedir. Kendinden sonraki aşamaların takip edecek sözcüklerden sıyırma ve yeniden ifade etme süreçlerini sağlıklı 
yürütebilmesi için çevirmen, kaynak metinde söylemek istenilen "her şeyi anlamak ve her şeyi anlaşlır kılmak zorundadır" (Laplace, 2005, s.46) ilkesiyle çeviri sürecine başlamalıdır. Burada kaynak metindeki söylemek istenilen ve anlam arasındaki eşitliğin önemi de, çeviri sürecindeki yorumlama işlemi esnasında çevirmenin karşısına çıkmaktadır (age, s.46). O halde Hurtado Albir’in de belirttiği gibi, "anlama, anlamın kavranılmasındaki yorumlayıcı süreçtir" (2005, s.168).

\subsection{Sözcüklerden sıyrılma}

Kaynak metnin çeviri sürecindeki anlama işini tamamlayan çevirmen, sözcüklerden sıyırma aşamasına geçer. Bu aşamanın amacı, çevirmenin okuduğu ya da duyduğu ifadeyi oluşturan tüm sözcüklerinden, anlamlarından ve göstergelerinden sıyırma ya da ayırmadır. Delisle bu aşamada anlamı şöyle tanımlar: "Anlam, sözcüklerinden sıyrılmış; yani tüm anlamlarından arındırılmış bir şekilde kavranılır" (1980, s.77). Lederer de bu aşamayı şöyle açılklar: "Bir metnin anlaşılmasının ve diğer bir dilde yeniden ifade edilmesinin arasındaki çeviri işleminin ulaştı̆̆ı evredir. Bilişsel ve duygusal bir anlamın kavranıldığı esnada dilsel göstergelerden kurtulma söz konusudur" (1994, s.212).

YÇK'nın diğer adı olarak bilinen Anlam Kuramı'nın temel ögesi “anlam”dır. Anlamdan ayrılmaz olan anlama aşamasının da temel noktası olan ve YÇK'yı diğer kuramlardan ayıran bir aşama olan sözcüklerinden sıyrılma aşamasıdır. O halde yorumlama işleminde "anlam" anlaşıldı ya da kavranıldı, şimdiki aşamada da tüm sözcüklerinden sıyrıldı. Çevirmen bu iki aşamayı ne kadar bilinçli gerçekleştirirse, son aşama olan "yeniden ifade etme" aşamasında yazarın ya da konuşmacının yerine geçerek ne söylemek istediğinin hedef dildeki eşdeğerliğine göre bir çeviri eylemi gerçekleştirir.

\subsection{Yeniden ifade etme}

Kaynak metni anlayan ve sözcüklerinden ayıran çevirmen, bu aşamada konuşmayı ya da yazılı ifadeyi hedef dilin özellikleri ve biçimine göre tekrar anlamlandırır, anlamlandırdığı ifadenin eşdeğerliğini doğrular ve yeniden en uygun şekilde hedef dilde ifade eder. Özellikle bu son aşamada, çevirmenin tüm birikimlerine ek olarak kendinin, yazarın ya da konuşmacının ve hedef dili oluşturan bireylerin düşünce boyutu önem taşımaktadır. Bu yüzden, özellikle yazın çevirisinde, yazarın kendi yazınını oluşturan temel ögelerin aktarımlarına çevirmenlerin çok dikkat etmeleri gerekmektedir. Kimi zaman bir argo ifade, kimi zaman dini bir söylem, kimi zaman da mizahi bir repliğin hedef dilde eşdeğer biçimde aktarılması gerekir. Kendilerine özgü dil özellikleri taşıyan yazın türlerinin çevirilerinin incelenmesinde, yeniden ifade etme aşaması dikkat çeken bir aşama olarak ortaya çıkmaktadır.

\subsection{Eşdeğerlik ve uygunluk}

Eşdeğerlik ve uygunluk, her çeviri sürecinde karşımıza çıkan önemli iki kavramdır. Bazı çeviri kuramları, çeviri işleminin temelinin bu iki kavram üzerine kurmuştur. Uygunluk, kaynak metne dilbilimsel olarak bağlı kalınarak yapılan bir çeviri işlemini temsil ederken, eşdeğerlik ise hedef dilin dilsel özelliklerinin yanı sıra sosyal ve kültürel özelliklerini taşıyan bir çeviri işlemine işaret etmektedir. Bu yüzden Lederer, yorumlayıcı çeviriyi eşdeğerlik yoluyla yapılmış bir çeviri; dilbilimsel çeviriyi de uygunluk ile yapılmış bir çeviri olarak adlandırmaktadır (1994, s.50).

Uygunluk işlemi, kimi çevirilerde anlaşılır olmayan ve yetersiz çevirilere neden olmaktadır. Bu yüzden, eşdeğerlik çevirinin olmazsa olmazlarındandır. Eşdeğerlikle bağdaştırılmayan bir çeviri işlemi, yazarın ne söylemek istediğini vermede zorluk çekecektir, hatta çoğu zaman yazarın hedef toplumda anlaşılmamasına neden olacaktır. Eşdeğerlik ve uygunluk ile ele alınan bir çeviri işlemi ara sıra sağlıklı 
aktarmalar türetse de, eşdeğerliği olmayan bir çevirinin başarılı bir çeviri olarak adlandırılması mümkün değildir. O halde "eşdeğerlik, hem iyice düşünülmüş bir yöntemin (görmeye ve hissetmeye çabalamanın) ve önsezinin (ne gördüğ̈nü ve hissettiğini ifade etmenin) sonucudur. Sahip olduğu tüm bilgiyle çevirmen tarafından yeniden ifade edilen bir yazarın eşsiz düşüncesinin diğer bir dildeki değişimidir" (age, s.55). Lederer'in bu tanımından yola çıkarak yukarıda ele alınan tüm bu durumu, eşdeğerlik-uygunluk farkı, şu alıntıyla özetlenebilir: "Elbette çevirinin bütünü, terimler ve sözcükler arasındaki uygunlukları kapsar, fakat sadece eşdeğerliklerin oluşumu sayesinde çeviri metne dönüşür. İşte, kuramımızın merkez ögesi burasıdır” (age, s.55). Merkez ögeyi en iyi şekilde yerine getiren çevirmenin YÇK'daki önemine de bir sonraki başlık altında değinilecektir.

\subsection{Yorumlayıcı çeviri kuramında çevirmenin yeri}

Bundan önceki başlıklarda YÇK’nin çevirmen odaklı bir kuram olduğunu ve özellikle YÇK'yi oluşturan aşamaların hepsinde çevirmenin önemi belirtilmiştir. Hurtado Albir, Çeviribilimde Yorumlayıcı Çeviri Kuramının Yeri başlıklı çalışmasında YÇK’nın çeviribilime katkılarından birisinin çeviri işleminde çevirmen olgusu olduğunu belirtmesidir (2005, s.166). Bu yüzden YÇK’ya göre, bir çeviri işlemi gerçekleştirilirken ya da bir çeviri metin çözümlemesi yapılırken çevirmen, anlama-sözcüklerden sıyırma-yeniden ifade etme aşamalarının merkezini oluşturacaktır. O halde Lederer’in şu açıklaması yerinde olacaktır: "Çeviri işlemini incelemek, çevirmenin çalışmasının çeşitli aşamalarını incelemeyi ifade eder, yani dilleri karşılaştırmak için yan yana koymak değil de, bir çevirmen tarafından bir metnin anlaşılması ve yeniden ifade edilmesi aşamalarının üzerinde durulmasıdır” (2005, s.92).

YÇK’nin bu aşamalarında çevirmenin çeviri kabiliyetinin yanı sıra dil ya da dil dışı yeterliği ve evrensel bilgi seviyesi de önemlidir. Bir dili bilmek ya da konuşmak, o dilin kültürüne ve geleneklerine hakim olmak anlamına gelmeyebilir. Bu yüzden, çevirmenin tüm bu bilgi ve yeterliklerinin bir araya gelmesi, çevrilecek metnin hedef dilde var olma olasılı̆̆ını kuvvetlendirir. Eğer söz konusu bir yazın metni ise, aynı zamanda yazarının ne demek istediğinin ve yazına özgü özelliklerinin hedef toplumda çok iyi algılanma olasılığını artırır. O yüzden, çevirmen elindeki metnin alanını çok iyi belirleyip kendi yeterliğine göre çeviri işlemini sürdürmelidir. Dili çok iyi bilen çeviriyi çok iyi yapar düşüncesi her ne kadar yanlışsa, her çevirmen de her alanda çeviriyi çok iyi yapar düşüncesi bir o kadar yanlıştır. Bu yüzden çeviri işlemi, titizlik gerektiren bir süreçtir.

Tüm bu düşüncelerden yola çıarak çevirmenin çeviri işlemi esnasında karar verdiği eylemler YÇK’nın temelini oluşturduğuna dikkat çekilmektedir. Bu kararların yazın türlerinin çeviri sürecinde nasıl alınması gerektiğini anlamak için bir sonraki başlıkta yazın çevirisinin türlerine göre çevirilerinin genel yapısı ve YÇK'ye göre incelemeleri üzerinde durulacaktır.

\section{Yazın çevirisi ve yorumlayıcı çeviri kuramına göre yazı türlerinin çevirilerinin incelemeleri}

Yazın alanı, kendisine özgü özelliklere sahip dünya tarihinde belirli bir döneme ve belirli bir yazın akımına mal olmuş birçok tür barındırmaktadır. Bu türlerin çevirileri söz konusu olduğunda, ilgili yazın türünün dil özellikleri ön plana çıkmaktadır ve bu dil özelliklerinin çevirmen tarafından ele alındığı çeviri süreçleri dikkat çekmektedir. Çünkü bir yazın eserinde olmazsa olmaz en önemli öge "dil"dir. Dil, bilim eserlerinin çevirilerinde araç olarak kullanılırken, yazın çevirisinde amaç olarak benimsenir ve ilgili yazın eseri varlığını onunla özleştirir (Yücel, 1978, s.77). Bu yüzden yazın eserinin varlığı hem kaynak dilinin hem de hedef dilinin gücüne bağlıdır. Öyle ki, Okay (1990)'ın şu ifadesi bu durumu 
desteklemektedir: “Edebiyatın gücü de, za'fı da kullandığı malzemenin hususiyetinden gelir. Kullandığı malzemeden, yani dilden, kelimelerden...” (akt: Vural, 2002, s.225). O halde çeviri sürecinde hedef dil de, kaynak metin dili kadar önem taşımaktadır. Burada yazın çevirmeninin izleyeceği yol en basit şekliyle şöyle ifade edilebilir: Yazın çevirmeni, ilgili yazın eserinin yazarının, ortaya çıktığı dönemin ve dahil olduğu yazın akımının genel özelliklerini ve özellikle ilgili yazın türünün dil özelliklerini iyi tanıyarak çeviri sürecine başlayabilir.

Takip eden alt başlıklarda Fransızcadan Türkçeye birden fazla çevirisi yapılmış yazın türlerinden öykü, roman, şiir ve tiyatro metinlerinin çevirileri Yorumlayıcı Çeviri Kuramına göre incelenecektir. Çevirmenlerin çeviri sürecindeki çeviri kararları ele alınacak olup, özellikle çevirmenin YÇK’nın da bir aşaması olan "anlama" aşaması üzerinde durulacaktır. YÇK için çeviri, anlama, sözcüklerden sıyırma ve yeniden ifade etmeden ibaret olduğu vurgulanmaktadır. Aynı zamanda YÇK’nın da diğer bir adı da olan "anlam"ın ve çeviri sürecindeki aşamasının dikkatlice yapılmadan sağlıklı bir çeviriden söz edilemeyeceğinin altı çizilmektedir. Çünkü yazın çevirisini sorunsal kılan hususlardan biri metinlerin değişmeceli dili, diğeri de eğretilemeli anlamlarının çevrilmesidir (Aksoy, 2002, s.53). Bu çerçevede ilgili yazın türüne ait eserlerin çevirileri YÇK'ye göre incelenerek bir çeviri sürecini incelemede YÇK'nın nasıl ele alındığını ve hangi aşamalarına değinildiğinin üzerinde durulacaktır.

\section{1. Öykü çevirisi}

Öykü, düzyazı ile kaleme alınan, gerçeğe veya hayal gücüyle oluşturulan olaylara dayanan ve aynı zamanda kısa ve ilgi çekici anlatı olan bir yazın türüdür. Nedensellik çerçevesinde anlatıma dayanan öykü, diğer yazın türleri gibi dilin en üst seviyede kullanılmasını gerektirir. Genel olarak öykü dilinin özellikleri şöyle sıralanabilir: sıkıştırılmış zaman diliminde yoğun bir atmosfer dili, daha dar bir anlatım dili, kurgusal bir dünya dili, gözlem gücünün yansıttığı dil... (Vural, 2002). O halde, bir öykü metni çevirisi söz konusu olduğunda bu dil özellikleri çevirmenin çeviri sürecini yönetecek unsurlar haline gelecektir.

Genel olarak öykün metninin çeviri sürecindeki dil özelliklerini çevirmen tarafından ele alınışını daha iyi gözlemlemek için bu başlıkta Guy de Maupassant'ın Ay Işığı (Claire de lune) adlı öyküsünün Fransızcadan Türkçeye çevrilmiş üç metni incelenecektir. Bu incelemede kaynak metin (KM) için1903 yllında Librarie Paul Ollendorf basımı; hedef metin bir (HM1) için 1943 yılında Sitare Sevin'in çevirdiği Hilmi Kitabevi basımı; hedef metin 2 (HM2) için 2008 yllında Tahsin Yücel'in çevirdiği Can Yayınları basımı, hedef metin üç (HM3) için 2018 yılında Hüsen Portakal’ın çevirdiği Cem Yayınevi basımı eserler ele alınacaktır. Bu eserlerden elde edilecek karşılaştırmalı bir örneklem tablosu ile öykü dilinin çevirisi ve çeviri süreci, YÇK çerçevesinde incelenecektir. Aşağıdaki Tablo 2, bu incelemeyi oluşturmaktadır.

\begin{tabular}{|c|c|c|c|}
\hline KM & HM1 & HM2 & HM3 \\
\hline $\begin{array}{l}\text { Il portait bien son nom de } \\
\text { bataille, l'abbé Marignan. } \\
\text { C'était un grand prêtre } \\
\text { maigre, fanatique, d'âme } \\
\text { toujours exaltée, mais } \\
\text { droite. Toutes ses } \\
\text { croyances étaient fixes, } \\
\text { sans jamais d'oscillations. } \\
\text { Il s'imaginait sincèrement } \\
\text { connaître son Dieu, } \\
\text { pénétrer ses desseins, ses }\end{array}$ & $\begin{array}{l}\text { Rahip Marignan harpte } \\
\text { kazandı̆̆ı namı hakkıyle } \\
\text { muhafaza ediyordu. } \\
\text { Uzun boylu, zayıf, } \\
\text { mutaassıp, müfrit } \\
\text { tabiatlı, fakat dosdoğru } \\
\text { bir papazdı. Sarsılmaz } \\
\text { ve sabit bir imanı vardı. } \\
\text { Allahını hulus ve } \\
\text { doğrulukla tanıdığını; } \\
\text { onun takdirine, } \\
\text { arzusuna, iradesine }\end{array}$ & $\begin{array}{l}\text { Savaş adı pek yarassırdı } \\
\text { Peder Marignan’a. İri, } \\
\text { zayıf bir papazdı, çok } \\
\text { dindardı, ruhu her } \\
\text { zaman coşkundu ya } \\
\text { doğruydu da. Bütün } \\
\text { inançları kesindi, } \\
\text { dalgalanma, kıpırdanma } \\
\text { olmazdı hiç. İçtenlikle } \\
\text { Tanrı'sını tanıdığını, } \\
\text { amaçlarını, isteklerini, }\end{array}$ & $\begin{array}{l}\text { Peder Marignanx’a, } \\
\text { savaştan yola çıkılarak } \\
\text { verilen adı çok } \\
\text { yakışıyordu: İri, zarif, } \\
\text { bağnaz, her zaman } \\
\text { coşkulu ve bildiğini } \\
\text { okuyan, kararsızlık } \\
\text { yaşamayan sabit inançlı } \\
\text { biriydi. Tanrısını bütün } \\
\text { samimiyetiyle tanıdığını, } \\
\text { amaçlarını, isteklerini, }\end{array}$ \\
\hline
\end{tabular}




\begin{tabular}{|l|l|l|l|}
\hline $\begin{array}{l}\text { volontés, ses intentions } \\
\text { (s.3). }\end{array}$ & $\begin{array}{l}\text { nüfuz ettiğini } \\
\text { zannederdi (s.9). }\end{array}$ & $\begin{array}{l}\text { niyetlerini bildiğini } \\
\text { düşlerdi (s.126). }\end{array}$ & $\begin{array}{l}\text { niyetlerini kavradığını } \\
\text { düşünürdü. } \\
\text { Eylül 1515'deki } \\
\text { Marignano savaşı } \\
\text { kastediliyor (Ç.N.) (s.55). }\end{array}$ \\
\hline
\end{tabular}

Tablo 2. Öykü metni çevirisi inceleme

Tablo 2'deki alıntılanan metinlerin karşlaş̧tırmalı incelemesine geçmeden önce, çeviri süreci öncesi aşamasında olduğu gibi YÇK'da da çevirmen, anlama, sözcüklerden sıyırma ve yeniden ifade etme aşamasında çevirmek için ele aldığı yazın eserinin türüne, yazarına ve dahil olduğu yazın akımına göz önünde bulundurmalıdır. Daha sonra ilgili yazın türünün dil özellikleri kendiliğinden yukarıda belirtilen unsurlara göre şekillenecektir.

Çevirmen Maupassant'ın Ay Işı̆̆ı adlı öyküsünün çeviri sürecini başlattığında, YÇK’nın anlam/anlama aşamasını oluşturacak öncelikle unsurlar şunlar olmalıdır: Maupassant'nın kendisini yetiştiren realist Flaubert'den izler taşıyan bir yazar; natüralist bir yazar; Zola'dan da farklı bir natüralist bir yazar; gerçeği deneyerek açılayan natüralizmde, gerçeğin kendisinden daha kesin ve inandırıcı bir yol izlemeye çalışan bir yazar... Daha sonra bu öyküyü okumuş olan çevirmenin, bir rahibin söz konusu olduğu; rahibin inancının sağlam olduğu ve kadınların varlığının onda bilinçsiz bir nefret yarattığı; özellikle kadınların sevgi ihtiyacının rahibi rahatsız ettiği; Maupassant’n, erkeğin kadını hor görmesinden ve aşağılamasından kaynaklı kadına çirkin bir imaj verdiği (Salomon, 1978, s.155) gibi öyküyü içeren ayrıntıları göz önünde bulundurması gerekmektedir.

Tablo 2'deki alıntılanan kısma gelince, bu öykünün de oluşturulmasında sıkıştırılmış zaman diliminin söz konusu olduğu; rahibin isminden ve rahibin betimlenmesinden dar anlatım ve gözlem dilinin hakim olduğu anlaşılmaktadır. Buradaki papazın adından ve HM3'ün çevirmenin notundan da anlaşlacağı üzere, öykünün ilk girişine dikkat edilmesi gerekmektedir. YÇK’nın anlama aşamasının önemi burada ortaya çıkmaktadır. Bu isim, "Marignano/Marignan" savaşını kastetmektedir. Marignan şavaşı, Rönesans'ın habercisi, dinin devlet yönetiminde etkisinin azalması ve savaşın diğer tarafı olan Papa'nın gücünün kırılması gibi olayları kapsamaktadır. Bu durumu öykünün sonunda rahibin, yeğeni ve yeğeninin sevgilisinin aşk dolu hallerine karşı gelemeyip belki de tanrı böyle istiyor deyip dönüp gitmesi, dini geleneklerinin baskısının azaldığına işaret etmektedir. Buradaki anlama aşaması öykü metninin bütününe yansıyacak olup, özellikle çevirmenin sözcüklerinden sıyırma aşamasına yardımcı olacaktır.

Öyküde bir papaz, dini bir kimlik söz konusu olduğundan ve hedef metin özellikleri göz önünde bulundurulduğundan HM1'in çevirmeninin yeniden ifade etme aşamasındaki eşdeğerlik kaygısı "iman, Allah, takdir" gibi tercihleri dikkat çekmektedir. Fakat HM2 ve HM3’ün çevirmenleri Hıristiyanlıkla alakalı bir çeviri yaptıklarını sözcüklerinden sıyrılma aşamasında dikkat ederek, yeniden ifade etme kararlarını özellikle "tanrı" kelimesiyle yapmaları daha eşdeğer ve daha uygun kılmaktadır.

Bu tablodaki diğer bir konu ise "fanatique" kelimesinin çevirisidir. HM1'in ve HM2'nin bu kelime için "bağnaz ve mutaassıp" seçimi eşdeğer bir yeniden ifade etme tercihidir. TDK bu iki kelimeyi eşanlamlı olarak ele alır: "Bir düşünceye, bir inanışa aşırı ölçüde bağlanıp ondan başka bir düşünce ve inanışı kabul etmeyen, mutaassıp, fanatik” (2019) . Fakat söz konusu bir dini kimlik ve dini ritüelleri gereği başka düşünceyi kabul etmediği için HM2'nin “dindar” tercihi YÇK'nın anlama sürecinin ve sözcüklerinden sıyırma işleminin daha detaylıca yaptığını göstermektedir. Toplumumuzda "bağnaz" daha kaba anlam içerse de, daha ılımlı görünen "mutaassıp" ile aynı anlamda olup burada eşdeğerliği yüksek olan yine "dindar" olacaktır. 
Bu başlıkta, sınırlı gözükse de bir tabloda bir öykü metninin ve dilinin çevirisinin çeviri sürecinin çevirmenler tarafından nasıl ele alındığı YÇK’ye göre incelenmeye çalışılmıştır. Yukarıdaki üç çevirmenin dönemlerine göre YÇK’nın aşamalarını ele aldığı ve özellikle anlama aşamasını öykünün yazar ve dönemine göre değerlendirdikleri düşünülmektedir. Ara sıra hedef metindeki ifade tercihlerinden dolayı çevirmenlerin yeniden ifade etme aşamaları kendi içlerinde hem uygun çeviri hem eşdeğer çeviri olarak ayrılsa da, öykü metinlerinin çevirisinin belirli bir işlem sırasıyla çeviri sürecinin başlatılması gerektiği ortaya çıkmıştır. Öykü metninin dilinin çevirisinde en çok karşılaşılan dar anlatım dili ve gözleme dayalı bir dil özellikleriyle bir kez daha karşılaşılmıştır. Bu yorum yukarıdaki tablo için yapılsa da, Maupassant'ın Ay Işı̆̆ı adlı öyküsünün tamamı ele alındığında öykü dilinin diğer özelliklerinin hakimiyeti çeviri süreçlerinde görülecektir. Aslında yazın türlerinden öykü, kimi zaman kısa süreli bir anlatıma ve yoğun betimlemesinden dolayı şiire; kimi zaman da düz yazı anlatımdan dolayı romana benzese de kendine özgü dilinin olduğunun ve doğal olarak çevirilerinin de bu düşünceyle yapılmasının bir kez daha altı çizilmiştir.

\subsection{Roman çevirisi}

Roman, gerçek ya da hayal gücüyle oluşturulan olaylara dayanan, insanın deneyimlerini ve toplumun olgularını ele alan, düzyazı ile kaleme alınan ve öyküye nazaran daha uzun anlatı olan bir yazın türüdür. Öyküye benzese de, aslında öyküdeki dar anlatımın daha geniş̧e yayıldığı ve yoğun atmosferin daha geniş bir betimlemeyle anlatıldığı bir tür olarak da tanımlanmaktadır. Daha geniş bir anlatımlı düzyazı olan roman metninin dili, hem anlaşılması hem çevrilmesi bakımından sorunsal gibi görünmese de, çevirisi söz konusu olduğunda kendi içinde her yazın türü gibi bir çeviri sorunu barındırmaktadır. Roman yazarının üslubu, eserinin basıldığı dönemin toplumsal, siyasi ve kültürel özellikleri ve eserin yer aldığı yazın akımının özellikleri roman metni dilini etkileyen unsurlar olarak burada da ortaya çıkmaktadır. Diğer yazın türlerinde de geçerli olan bu unsurlar roman metninin dilinin çevirisinde, eserin geneline yansıyan bir anlatım söz konusu olduğundan, daha önemli hale geldiği düşünülmektedir.

Roman metninin genel olarak çeviri sürecindeki dil özelliklerini çevirmen tarafından ele alınışını daha iyi gözlemlemek için bu başlıkta Émile Zola'nın Hayvanlaşan İnsan (La bête humaine) adlı romanının Fransızcadan Türkçeye çevirisi yapılmış üç metni incelenecektir. Bu incelemede Fasquelle'in 1997 basımını kaynak metin için; Hamdi Varoğlu'nun çevirisini yaptı̆̆ 1969 yılında Remzi Kitabevi'nin basımı hedef metin bir için; Alev Özgüner’in çevirisini yaptı̆̆ı 2018 yılında Türkiye İş Bankası Kültür Yayınları basımı metin iki için; İlhan Cem Erseven’in çevirisini yaptığı 2018 yılında İmge Kitabevi basımı da hedef metin üç için ele alınacaktır. Bu eserlerden elde edilecek karşılaştırmalı alıntılardan oluşan bir örneklem tablosu ile roman metni dilinin çevirisi ve çeviri süreci YÇK’nn aşamaları çerçevesinde incelenecektir. Aşağıdaki Tablo 3, bu incelemeyi oluşturmaktadır.

\begin{tabular}{|c|c|c|c|}
\hline $\mathbf{K M}$ & HM1 & HM2 & HM3 \\
\hline $\begin{array}{l}\text { Il n'acheva pas, termina du } \\
\text { geste, pendant que le juge, } \\
\text { silencieux à son tour, } \\
\text { attendait d'un air morne les } \\
\text { ordres qu'il sentait venir. Du } \\
\text { moment où l'on acceptait sa } \\
\text { vérité à lui, cette création de } \\
\text { son intelligence, il était prêt } \\
\text { à faire aux nécessités } \\
\text { gouvernementales le } \\
\text { sacrifice de l'idée de justice. } \\
\text { Mais le secrétaire, malgré }\end{array}$ & $\begin{array}{l}\text { Lakırdının arkasını } \\
\text { getirmedi, sözünü bir el } \\
\text { hareketiyle bitirdi. Yargıç } \\
\text { da, susuyor, verileceğini } \\
\text { sezdiği emirleri, tasalı bir } \\
\text { tavırla bekliyordu. Kendi } \\
\text { bulduğu hakikatı, kendi } \\
\text { zekasının yarattığı o eseri } \\
\text { kabul ediyorlardı; adalet } \\
\text { kavramını, hükümet } \\
\text { gereklerine feda etmeye } \\
\text { hazırdı. Fakat, sekreter, } \\
\end{array}$ & $\begin{array}{l}\text { Elini şöyle bir savurdu } \\
\text { ve cümlesini yarıda } \\
\text { biraktı, o sırada yargıç } \\
\text { susuyor ve tasalı bir } \\
\text { tavırla, birazdan } \\
\text { kendisine verileceğini } \\
\text { hissettiği emirleri } \\
\text { bekliyordu. Kendi } \\
\text { gerçeğini, kendi } \\
\text { zekâsının ürünü olan } \\
\text { bu keşfi kabul ettikleri } \\
\text { andan itibaren, adalet } \\
\end{array}$ & $\begin{array}{l}\text { Konuşmanın arkasını } \\
\text { getirmedi, sadece bir el } \\
\text { hareketiyle sözünü } \\
\text { bitirdi. Yargıç da } \\
\text { susmuş, kendisine } \\
\text { verileceğini sezdiği } \\
\text { talimatları kaygılı bir } \\
\text { tavırla bekliyordu. } \\
\text { Zekasının ürünü olan bu } \\
\text { eseri, kendi gerçeğini } \\
\text { kabul ettiği andan beri, } \\
\text { adalet düşüncesini, }\end{array}$ \\
\hline
\end{tabular}




\begin{tabular}{|c|c|c|c|}
\hline $\begin{array}{l}\text { son habituelle adresse en ces } \\
\text { sortes de transactions, se } \\
\text { hâta un peu, parla trop vite, } \\
\text { en maitre obéi (s.183). }\end{array}$ & $\begin{array}{l}\text { bu gibi işlerde her zaman } \\
\text { usta olduğu halde biraz } \\
\text { acele etti. Emrine itaat } \\
\text { edilen bir amir olarak, } \\
\text { fazla çabuk konuştu } \\
\text { (s.139). }\end{array}$ & $\begin{array}{l}\text { kavramını siyasi } \\
\text { gerekliliklere feda } \\
\text { etmeye hazırdı. Ama } \\
\text { sekreter, uzlaşmalar } \\
\text { konusunda her zaman } \\
\text { usta olmasına rağmen, } \\
\text { biraz aceleci davrandı; } \\
\text { itaat edilen bir amir } \\
\text { olmanın alışkanlığı ile } \\
\text { hızlıca girdi konuya } \\
\text { (s.147). }\end{array}$ & $\begin{array}{l}\text { siyasetin gereklerine } \\
\text { feda etmeye hazırdı. } \\
\text { Fakat sekreter, bu gibi } \\
\text { uzlaşmalarda her } \\
\text { zamanki ustalığına } \\
\text { karşın biraz aceleci } \\
\text { davrandı; verdiği } \\
\text { emirleri yerine getirilen } \\
\text { bir amir tavrıla çabuk } \\
\text { çabuk konuştu (s.131). }\end{array}$ \\
\hline
\end{tabular}

Tablo 3. Roman metni çevirisi inceleme

Tablo 2'de olduğu gibi Tablo 3'de de, çevirmenlerin YÇK'nın aşamalarına daha iyi yapabilmeleri için yukarıda da bahsedildiği üzere romanın yazarı, dönemi ve akımı hakkında bilgi sahibi olmaları gerekmektedir. Daha sonra çeviri sürecine geçildiğinde, Zola'nın Hayvanlaşan İnsan romanının çeviri sürecinin ön hazırlığını oluşturan ve YÇK’nın aşamalarını merkezinde olan unsurlar şöyledir: Zola’nın natüralist bir yazar olması, gerçekliği deney yoluyla açıklaması, insanın özünü ve insanlığı bireyin kendinden ziyade bireyin toplumdaki yeriyle açıklaması, genel olarak ağır ve kaba dil kullanması. Ayrıca bu romanın, tüm gelişmelere rağmen ilkel insanın ilkelliğini koruduğu; yargı ve işçi sınıfının hayatlarının anlatıldığı; romanın isminin ve romanın konusundaki tren nesnesinin bir metafor olarak kullanıldığı; ikinci imparatorluktan izler taşıdığı çevirmenlerin YÇK’nın tüm aşamalarında adeta kendini kontrol eden bir sistem gibi göz önünde bulundurmaları gereklidir.

Tablo 3'deki alıntıya gelince, Başkan Grandmorin'in öldürülmesiyle ilgili atanan sorgu yargıcı M. Denizet’in, Adalet Bakanlığının Genel Sekreteri M. Camy-Lamotte’un vereceği talimatları önceden kestirdiği ve özellikle sekreterin konutuna davet edildiği için özel emirler alacağını bildiği için, sekreterin yaptığı konuşmaya yönelmek yerine kafasında davayı nasıl sürdüreceğini düşünmektedir. Böyle bir durumda, HM1'in çevirmeninin "sonunu getirmek, bitirmek" anlamına gelen "achever" fiilini kullanması, çeviri sürecinin anlama sürecinde yukarıdaki bahsettiğimiz duruma hakim olmuş ki yeniden ifade aşamasında "lakırdının arkasını getirmedi" şeklinde eşdeğerlik gösteren bir çeviri kararı alması sözcüklerinden sıyırma aşamasının da iyi yapıldığını doğrulamaktadır. Bu çeviri kararı, aynı zamanda dönemin adalet sistemi ile ilgili Zola'nın da eleştirdiği duruma küçük de olsa gönderme yapmaktadir.

Bu tabloda dikkat çeken diğer bir ifade ise "nécessités gouvernementales"dır. HM2 ve HM3 bu ifadeyi, "siyasi gereklilik" olarak yeniden ifade etse de, aslında roman tam anlamıla yorumlanacak ve İkinci İmparatorluğun ve bir yönetimin/hükümetin varlığına işaret edildiği düşünülecek olursa HM1’in "hükümet gerekleri" tercihi anlama ve sözcüklerinden sıyırma aşamasında bu duruma işaret ettiği düşünülmektedir. HM2 ve HM3'de bu ifade, günümüzdeki hükümeti yönetenlerin siyasetini kasteden bir anlama dayandırıldığından eşdeğer bir yeniden ifade etme aşaması söz konusudur. Her iki çevirmenin sözcüklerinden sıyırma aşamasında aldığı kararlar dönemlerine göre eşdeğer olarak nitelendirilebilirler.

Roman Çevirisi başlı̆̆ında, bir roman metninin ve dilinin çevirisinin çeviri sürecinin çevirmenler tarafından nasıl ele alındığı YÇK’ye göre incelenmeye çalışılmıştır. Yukarıdaki üç çevirmenin aldıkları çeviri kararları dönemlerine göre ve tabloda bulunan ifadelerin çevirilerinin basıldıkları döneme göre eşdeğerlik taşıdığı ve bu doğrultuda YÇK’nın aşamalarını çeviri sürecinde yönlendirdikleri düşünülmektedir. HM1'in çevirmeni bu tablodaki örnekleme göre verdiği çeviri kararlarından YÇK'nın anlama aşamasını diğerlerine göre farklı ele alması küçük bir fark olarak ortaya çıssa da, burada 
vurgulanmak istenilen yeniden ifade etme aşamasındaki alınan çeviri kararının son hali aslında çevirmenin anlama ve sözcüklerinden sıyırma aşamasının nasıl ele aldığını göstermektedir. Bu durum tüm çeviri süreçlerini kapsasa da, daha geniş anlatım diline sahip roman metni dilinin çevirisinin özellikleri burada ortaya çıkmaktadır. Zola'nın Hayvanlaşan İnsan adlı romanının bütününe yayılan işçi sınıfının, yargı sisteminin ve dönemin imparatorluğunun eleştirisinin dili de YÇK’nın tüm aşamalarının merkezinde olup çevirmenlerin hedef metin dilinde bu yönde kararlar alması gerektiği anlaşılmaktadır. Bu düşüncelerden yola çıkarak roman dilinin bir cümle, sayfa ve bölüm ile sınırlı kalmayacağı, roman metninin bütününe yayıldığı ve çeviri sürecini yönlendirecek YÇK’nın aşamaları gibi süreçlerin alınacak çeviri karalarının temelini oluşturduğu bu başlıkta vurgulanmaya çalışılmıştır.

\section{3. Şiir çevirisi}

Şiir, dilin estetik, ses, ritim gibi özelliklerini sözcükler aracıllğıyla en üst seviyede kullanan bir yazın türüdür. Dili en üst seviyede kullanma; hissedileni, betimleneni ve düşünülenini bir ya da birkaç sözcük ile anlatma; söz sanatlarını kullanma şiirin ve özellikle şiir dilinin ilk akla gelen özelliklerindendir. Yazılı bir tür olsa da, sesli okunmak için de kaleme alınan özelliğiyle tiyatro gibi diğer yazın türlerinden ayrılır. Diğer yazın türleri gibi, şiir dili de çeviri çalışmalarında bir sorunsal oluşturmaya devam etmektedir. Genel olarak şiir dilinin çevrilemezliği konusunun yazın çevirisinde güncelliğini korumasının en önemli nedeni, şairin kimi zaman bir, kimi zaman birkaç sözcükle büyük, yoğun ve derin duygular ve düşünceler anlatmasıdır. Belki de şiir çevirmeni için, "şiir çevirmenin de şair olması gerekir" düşüncesi buradan kaynaklanmaktadır. Bu durum şiir dilinin çevirisini kendine özel kılsa da, aslında tüm diğer yazın türlerinde de böyle düşünüldüğü gözlemlenmektedir. Çünkü yazın çevirmeni, aynı zamanda bir yazardır.

Genel olarak şiir metninin çeviri sürecindeki dil özelliklerini çevirmen tarafından ele alınışını daha iyi gözlemlemek için bu başlıkta da Gérard de Nerval'in Les Cydalises adlı şiirinin Fransızcadan Türkçeye çevrilmiş üç metni incelenecektir. Bu incelemede kaynak metin için 1964 yılındaki Us Yayınları basımı; hedef metin bir için 1964 yılında H. Kaya Öztaş’ın çevirdiği Us Yayınları basımı; hedef metin iki için 1976 yllında Sabahattin Eyüboğlu ve Orhan Veli’nin çevirdiği Cem Yayınevi basımı; hedef metin üç için 1994 yılında Erdoğan Alkan’ın çevirdiği Broy Yayınları basımı eserler ele alınacaktır. Bu eserlerden elde edilecek karşlaş̧tırmalı bir örneklem tablosu ile şiir dilinin çevirisi ve çeviri süreci, YÇK çerçevesinde incelenecektir. Aşağıdaki Tablo 4, bu incelemeyi oluşturmaktadır.

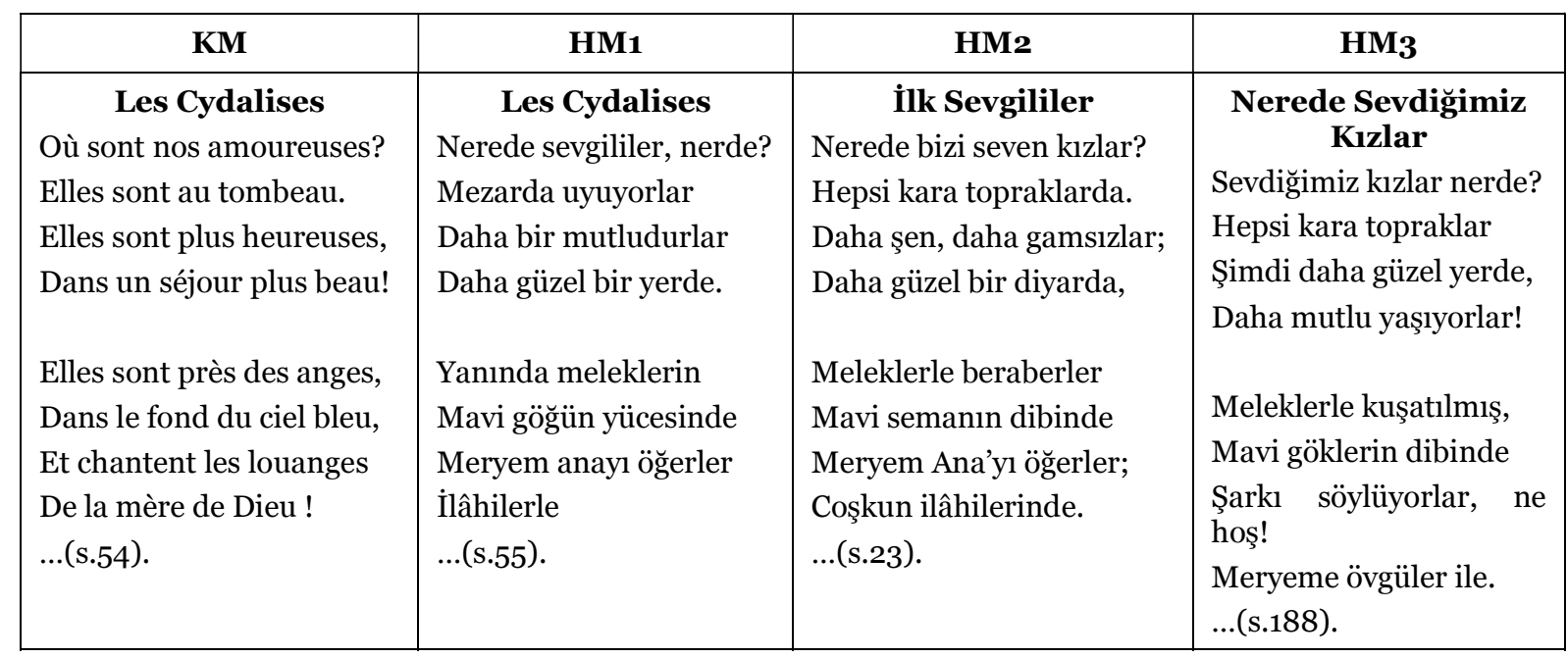

Tablo 4. Şiir metni çevirisi inceleme 
Diğer yazın türlerinin incelemelerinde olduğu gibi, Tablo 4'de de çevirmenlerin şiirin şairinin, döneminin ve dahil olduğu yazın akımı hakkında bilgi sahibi olmasının yanı sıra, dönemin şiir estetiğinin ve ölçüsünün özelliklerini de bilmesi gerekmektedir. Ayrıca Ahmet Haşim’in de şiir dili için sıraladığı şu özellikleri çeviri sürecinin ve YÇK’nın şiir dili çeviri sürecinin aşamalarının merkezinde olmalıdır: "Okurda duygu ve izlenim uyarır; ezgilidir; sözcükler ikinci, üçüncü yeni (gölge) anlamlar taşır; sözdiziminde sözcükler, hatta sözcüklerin harfleri birbirleriyle uyum içindedir, tarzı ve edası bir başka ölçeğe, şairin dehasına göre düzenlenmiştir; genel dilden ayrıdır” (akt: Alkan, 2005, s.600).

Daha sonra Gérard de Nerval'in Les Cydalises adlı şiirinin çevirisi sürecine geçildiğinde, çevirmenin anlama, sözcüklerinden sıyırma ve yeniden ifade etme aşamalarını oluşturacak unsurlar şöyledir: Nerval'in bir romantizm akımının şairi olması, romantizmle Fransız yazınının dilinin değişmesi, her kesim ve her şeyin şirin konusu olabileceği, şiirin artık duyguları anlatan bir dil olması, zengin uyakların gözden düşmesi, yunan ölçülerinin yerini ulusal Fransız ölçüsü alexandrin'lerin alması, biçim çabasının yerini lirizm alması, doğa ve insanın kaynaştığı bir dilin romantik şiirde hakim olması (Alkan, 1994, s.40-41). Les Cydalises şiirinin Küçük Aylaklk Şatoları (Petits châteaux de Bohême) serisinde yer alması çevirmenin anlama sürecini etkileyecek diğer konulardan biri olup, çevirmenlerin bu seri içinde yer alan diğer şiirler hakkında da bilgi sahibi olmasının gerekliliği ortaya çıkmaktadır. Nerval, bu şiirin kendine lirikten ziyade şarkı sözleri gibi geldiğini, dizeleriyle birlikte bir ezgi yakaladığını ve bu yüzden notaya başvurduğunu belirtir (akt: Alkan, 1994, s.51). Belki de bu kadar detay çevirmenin şair olması gerekliliği düşüncesini akla getirse de, şiir dilinin çevirisi için de izlenecek aşamalar da diğer yazın türlerinden farklı olmayacaktır. Bu yüzden, yukarıdaki özelliklerin ve unsurların YÇK’nın ilk aşaması olan anlama aşamasının merkezinde olması ve diğer aşamaların da bu bilgilere göre yapılması gerekliliği vurgulanmaktadir.

Tablo 4'ün incelemesinde, şiirin başlığının her bir hedef metinde farklı olarak ele alındığı gözlemlenmektedir. "Cydalises”in, Yunanca "kudos" (ün, şöhret) ve "lusis" (yok olma) kökünden türemiş olabileceği ve Nerval'in de bunu ses uyumu olarak kullandığı bir kanı olarak ortaya çıkmaktadır. Bu yüzden hedef metin 2-3'ün çevirmenlerinin ilk mısradan yola çıkarak bir anlama ve sözcüklerinden sıyırma işlemi gerçekleştirmeleri dikkat çekmektedir. Ayrıca başlık çevirisi tercihlerinden mısranın sonundaki kafiye uyumu da, çevirmenlerin yeniden ifade etme aşamalarına uygunluk sağlamaktadır. HM1'in çevirmeni başlıkla ilgili hiçbir çeviri kararı almamıştır. Bu da YÇK’nın anlama ve sözcüklerinden sıyırma aşamasındaki sürecin olduğu gibi kaldığı, bu yüzden çevirmenin yeniden ifade etme kararını olduğu gibi bırakmadan yana kullandığı düşünülmektedir.

2. kıtada, "la mère de Dieu" ifadesi dikkat çekmektedir. Her bir çevirmen YÇK’nın sözcüklerinden sıyırma aşamasında bu ifadenin aktarılacak olan kültürüne, özellikle dini özelliklerini göz önünde bulundurarak; Hıristiyan aleminde diğer bir adı "Tanrı'nın Anası" olarak da adlandırılan "Meryem” veya "Meryem Ana" olarak yeniden ifade etmektedirler. Ancak, HM1 ve HM2'nin çevirmenlerinin hedef toplumda bu dini kimliğin anıldı̆̆ isimlerden olan "Meryem Ana" tercihi, sözcüklerden siyırma aşamasında bu durumu göz önünde bulundurduğunu ve bu doğrultuda yeniden ifade etme aşamasını eşdeğer bir şekilde yaptığını göstermektedir. HM3’ün bu ifadeyi sadece "Meryem" olarak bırakması, bağlam olarak "Meryem Ana"yı çağrıştırsa da, sadece "Meryem" tercihi eşdeğerlikten ziyade daha çok uygunluk taşımaktadır. Yine aynı kıtada "chanter des louanges" ifadesi çevirmenlerin anlama aşamasının nasıl gerçekleştiğini göstermektedir. Özellikle YÇK’nın sözcüklerinden sıyırma aşamasında bu kıtanın dini ifadelerle dolu olduğunun çevirmenler tarafından kavranıp ona göre eşdeğer ve uygun önermeler eşliğinde yeniden ifade edilmesi söz konusudur. HM3’ün çevirmeni, "birini övmek, övgüler düzmek" (Saraç, 2003, s.842) anlamına gelen "chanter des louanges de qn" kalıbının sözcüklerinden 
sıyrılma aşamasında "chanter" ve "louanges" kelimelerine yoğunlaşarak "şarkı söylemek-övgüler" şeklinde eşdeğerlikten ziyade uygunluk içeren yeniden bir ifade etme kararı almıştır. Halbuki bu kıta dini söylemler içeren bir kıta olup, aslında "chanter la louange” ifadesini doğru yorumlamak gerekir. Hedef kültürde ilahi, "Tanrı'yı övmek, ona dua etmek için yazılıp makamla okunan nazım” (TDK, 2019) olarak tanımlanmaktadır. Bu yüzden HM1 ve HM2'nin çevirmenlerinin YÇK’nın çeviri süreçlerinden özellikle anlama ve sözcüklerinden sıyrılma işlemini sağllklı bir şekilde gerçekleştirdiği gözlemlenmektedir. Ayrıca bu çevirmenlerin "ilahi-Meryem Ana" tercihleri çevirilerini eşdeğer bir çeviri yaparken, HM3’ün çevirmenin "şarkı-Meryem” tercihi ise, çevirisini uygunluk içeren bir çeviri yapmaktadır.

Bu başlıkta, bir şiir metninin ve dilinin çevirisinin çeviri sürecinin çevirmenler tarafından nasıl ele alındığı YÇK’ye göre incelenmeye çalışılmıştır. Yukarıdaki dört çevirmenin aldıkları çeviri kararları birbirinden ayrılsa da, her birinin YÇK’nın aşamalarını kendi şiir anlayışlarına göre değerlendirdikleri düşünülmektedir. Çünkü ortaya çıkan her bir hedef metinde farklılıklar mevcut ve bu da YÇK’nın her bir aşamasında çevirmenin bireysel yazın birikimini ve şair yanını göstermektedir. Ayrıca yukarıdaki tabloyu oluşturan otuz kadar kelimeyle romantizmin gibi bir yazın akımının şiir özelliklerini ve Nerval gibi şairinin duygu ve düşüncelerini hedef metne aktarmanın kolay bir iş olmadığı çevirmenlerin YÇK'nın aşamalarında aldıkları kararlarından anlaşılmaktadır. Tüm şiir çevirilerinde olduğu gibi, Nerval'in Les Cydalises adlı şiirinin çevirisinde de mümkün olduğunca Nerval'in yaşadığı döneme ait duygu ve düşüncelerine en üst seviyede ulaşmak, çeviri sürecini esnasında ve YÇK’nın aşamalarında çevirmenin daha doğru, uygun ve eşdeğer çeviri kararları almalarını sağlayacaktır. Aslında bu durum tüm yazın türlerinin çevirileri için geçerli olsa da, şairin birkaç kelimeye sığdırdığı his, betim ve duyguyla birlikte söz sanatlarını kullanmasından dolayı yazın çevirisi alanında şiir çevrisinin yerinin farklı olmaya devam edeceği düşünülmektedir.

\subsection{Tiyatro çevirisi}

Her türlü oyunların oynandığı ve izlendiği yer olarak tanımlansa da, tiyatro; oyunların, oyuncular tarafından seyirciler önünde sahnelenmesi amacıyla hazırlanmış bir tür sahne sanatıdır. Sahnelenmek amacıyla kaleme alındığından tiyatro, hem bir sahne sanatı hem de bir yazın türüdür. Diğer yazın türleri gibi yazılı bir metni olan tiyatronun, ayrıca bir sahnesi ve bu sahnenin yönetmen, oyuncu, dekor ve seyirci gibi önemli unsurları vardır. O halde tiyatro oyun metninin özellikle dilinin çevirisi söz konusu olduğunda yazarın, döneminin ve bağlı olduğu yazın akımı kadar sahne dilinin de önemli olduğu ortaya çıkmaktadır. Çünkü geçmişte olduğu gibi günümüzde de tiyatro metni, çoğu çevirmen tarafından çeviri sürecinde sadece bir yazın türü metni olarak görülmekte, tiyatro oyunun aynı zamanda sahnelenebilir bir dile sahip olması gerektiği ve yazarın kimi zaman bir replikte kimi zaman bir dekorda estetik kaygısına sahip olduğu unutulmaktadır. İşte burada tiyatro oyun metninin çevirisinin sorunsalı da ortaya çıkmaktadır.

Bu başlıkta, tiyatro oyun metninin çeviri sürecindeki dil özelliklerinin çevirmen tarafından ele alınışını daha iyi gözlemlemek için Eugène Ionesco'nun Kel Şarkıcı (La Cantatrice chauve) adlı oyunun Fransızcadan Türkçeye çevrilmiş iki metni incelenecektir. Bu incelemede kaynak metin için 1991 yllındaki Gallimard basımı; hedef metin bir için Ülkü Tamer ve Genco Erkal’in çevirdiği 1965 yllındaki De Yayınevi basımı; hedef metin iki için Hasan Anamur'un çevirdiği 1997 yllındaki Mitos Boyut Yayınları basımı eserler ele alınacaktır. Bu eserlerden elde edilecek karşıllaştırmalı bir örneklem tablosu ile tiyatro oyun metninin dilinin çevirisi ve çeviri süreci, YÇK çerçevesinde incelenecektir. Aşă̆ıdaki Tablo 5, bu incelemeyi oluşturmaktadır. 


\begin{tabular}{|c|c|c|}
\hline KM & HM1 & HM2 \\
\hline $\begin{array}{l}\text { Mme. MARTIN Je peux acheter un } \\
\text { couteau de poche pour mon frère, } \\
\text { mais vous ne pouvez acheter } \\
\text { l'Irlande pour votre grand-père. } \\
\text { M. SMITH On marche avec les } \\
\text { pieds, mais on se réchauffe à } \\
\text { l'électricité ou au charbon. } \\
\text { M. MARTIN Celui qui vend } \\
\text { aujourd'hui un bœuf, demain aura } \\
\text { un œuf. } \\
\text { Mme. SMITH Dans la vie, il faut } \\
\text { regarder par la fenêtre. } \\
\text { Mme. MARTIN On peut s'asseoir } \\
\text { sur la chaise, lorsque la chaise n'en } \\
\text { a pas. } \\
\text { M. SMITH II faut toujours penser à } \\
\text { tout. } \\
\text { M. MARTIN Le plafond est en haut, } \\
\text { le plancher est en bas. } \\
\text { Mme. SMITH Quand je dis oui, } \\
\text { c'est une façon de parler. } \\
\text { Mme. MARTIN A chacun son } \\
\text { destin. } \\
\text { M. SMITH Prenez un cercle, } \\
\text { caressez-le, il deviendra vicieux! } \\
\text { (s.38-39). }\end{array}$ & $\begin{array}{l}\text { BAY SMITH. Insan ayaklariyle } \\
\text { yürür, ama elektrik ya da kömürle } \\
\text { ısınır. } \\
\text { BAY MARTIN. Bugün bir öküz } \\
\text { satanın yarın bir yumurtası olur. } \\
\text { BAYAN SMITH. Ben evet dediğim } \\
\text { zaman muhakkak lâfın gelişidir. } \\
\text { BAYAN MARTIN. Herkese kendi } \\
\text { kaderi. } \\
\text { BAY SMITH. Bir daire al, biraz } \\
\text { okşa, canavar kesilir (s.45). }\end{array}$ & $\begin{array}{l}\text { BAYAN MARTİ: Ben kardeşime } \\
\text { bir çakı satın alabilirim, ama siz } \\
\text { büyük babanıza İrlanda'yı satın } \\
\text { alamazsınız. } \\
\text { BAY SMİTH: İnsanlar ayaklarıyla } \\
\text { yürürler, ama elektrikle ya da } \\
\text { kömürle ısınırlar. } \\
\text { BAY MARTİ: Bugün bir inek } \\
\text { satan yarın bir sinek alır. } \\
\text { BAYAN SMİH: Insan yaşamda } \\
\text { pencereden bakmalıdır. } \\
\text { BAYAN MARTİN: Sandalyeye } \\
\text { oturulabilir, eğer } \\
\text { sandalye yoksa. } \\
\text { BAY SMİTH: Her zaman her şeyi } \\
\text { düşünmek gerekir. } \\
\text { BAY MARTİN: Tavan yukarıdadır, } \\
\text { yerse aşağıda. } \\
\text { BAYAN SMİTH: Evet dediğim } \\
\text { zaman hep laf olsun diyedir. } \\
\text { BAYAN MARTIN: } \\
\text { yazgısı kendisinedir. } \\
\text { BAY SMİTH: Bir döngü alın, biraz } \\
\text { okşayın, hemen kısırlaşır! } \\
\text { (s.73-74). }\end{array}$ \\
\hline
\end{tabular}

Tablo 5. Tiyatro metni çevirisi inceleme

Tablo 5'de diğer yazın türlerinin incelemelerinde olduğu gibi çevirmenlerin tiyatro oyununun yazarının, döneminin ve dahil olduğu yazın hakkında ön bilgiye sahip olması gerekmektedir. Bunun yanı sıra tiyatro oyunu çevirmeninin çeviri sürecini sahne ve oyun diline göre yönlendirmesi, hedef metindeki tercihlerini sahnelenebilir bir tiyatro metni dilinden yana kullanması ve "oyuncuların bedenlerinden ve seyircilerin kulaklarından geçen bir dilde” (Pavis, 1999, s.153) yoğunlaşması, olmazsa olmaz aşamalar olarak ortaya çlkmaktadır.

Daha sonra Eugène Ionesco'nun Kel Şarkıcı adlı tiyatro oyununun çevirisi sürecine geçildiğinde, çevirmenin anlama, sözcüklerinden sıyırma ve yeniden ifade etme aşamalarını oluşturacak unsurlar şöyledir: Ionesco'nun absürd tiyatronun öncülerinden olup tiyatronun dilinde en köklü değişikliği yapması; oyunlarının dili anlamsızlık, iletişimsizlik, dil oyunları ve tekrarlamalar üzerine kurulu olması. Anlama aşamasının merkezine bu unsurları yerleştiren tiyatro oyunu çevirmenleri çeviri sürecinin gidişatını Kel Şarkıcı oyunun özellikleriyle kuvvetlendirebilirler. Örneğin, Ionesco'nun anlamsızlığı, iletişimsizliği, dil oyunlarını ve tekrarlamalar gibi kendi özgü kavramları oyunda seyirciye hissettirmesi; İngilizce ve İngiliz burjuvazisini eleştirdiği bir oyun olması; sahnenin ve sahneyi oluşturan unsurların "dili” üzerine bir oyun olmakla birlikte bu unsurların her birinin iletişime geçmek istemesi fakat geçememeleri gibi özellikler çevirmenlere çeviri sürecinde alacağı kararlar açısından yardımcı olacağı düşünülmektedir.

Tablo 5’in Ionesco tiyatrosunun dil özelliklerini ve çeviri süreçlerini değerlendirmede sinırlı olacağı, fakat Ionesco gibi kendine özgü dil özelliklerine sahip tiyatro yazarı ve türlerinin çeviri süreçlerini ışı tutacağı düşünülmektedir. Bu tablonun incelemesine de gelince, Ionesco tiyatrosunun "anlamsızlık" 
özelliği, yukarıdaki örneklemi oluşturmaktadır. İtfaiye Şefi'nin gidişinden sonra yalnız kalan Smith ve Martin çiftinin anlamsız cümleler ve ifadelerden oluşan bir diyalogun içinde kendilerini buldukları sahneyi ele alır. YÇK’nın merkezinde bulunan çevirmenin "anlamsızı", anlam ve anlama aşamalarından geçirmesi bir o kadar önem arz etmektedir. HM1’in çevirmeni, kaynak metnin beş cümlesini çevirmediği gözlemlenmektedir. YÇK’nın aşamalarını yerine getirerek, özellikle dilbilimsel bakımdan uymaya çalışarak uygun bir çeviri yaptığı şeklinde nitelendirilmektedir. Çevirmen burada anlama sürecinde, belki de bu kadar çok anlamsız cümlenin çokluğunda sahneleme kaygısından dolayı kısıtlamaya gitmiş olması muhtemel olarak görülmektedir. Bu yüzden diğer YÇK’nın süreçlerini böyle değerlendirmiş olduğu düşünülmektedir.

HM2'de kaynak metne bağlı kalarak hem eşdeğer hem de uygun bir çeviri yapılmıştır. Anlamsızlık HM1'de de vurgulansa da, HM2'de bir bütünlük halinde olduğu için bu örneklemdeki anlamsızlık daha iyi vurgulanmıştır. Özellikle ikinci cümledeki HM2'nin çevirmeni “un boeuf-un oeuf” ses uyumunu fark eder ve yeniden ifade etme aşamasını "inek-sinek" şeklinde yorumlayarak eşdeğer bir çeviri gerçekleştirir. Bunu yaparken hem kaynak metne bağlı kalır hem hedef dile uyum sağlar hem de absürd tiyatronun özelliği olan anlamsızlık içindeki dil oyununu verir.

Ne Tiyatro Çevirisi başlığı ne de diğer yazın türlerinin çevirilerini ele alan başlıklar bu düşüncelerle ve örneklemlerle sınırlandırılamaz. Özellikle birçok dil özelliği barındıran Ionesco tiyatrosu hem tiyatro alanında hem de tiyatro çevirisi alanında ayrı bir yere sahiptir. Yukarıdaki tabloda, her üç çevirmen de çeviri sürecinin anlama aşamasında Ionesco'nun dil özelliklerini temel almışlardır. Fakat, kimi zaman bir dönemin, kimi zaman bir yayınevinin, kimi zaman bir tiyatro topluluğunun kimi zaman da bir yönetmenin sahne kaygılarından dolayı tiyatro yazarının estetik ve dil özellikleri, hem kaynak metnin dilinde hem de hedef metnin dilinde sahne ve çeviri kayılarıyla karşılaşılabilmektedir. Tiyatro oyunu metni bu özelliğiyle diğer türlerden ayrıldığı gibi çevirileri için de bir sorunsal teşkil etmektedir. Ionesco'nun en önemli oyunu olarak adlandırılan Kel Şarkıcı'nın çevirisi yapılırken çevirmenlerin her birinin YÇK'nın çeviri sürecinde en iyi şekilde anlama, en iyi bir şekilde sözcüklerinden sıyırma ve en iyi şekilde hem uygun ve hem eşdeğer şeklide yeniden ifade etme kaygısı taşımaları gerekmektedir. Bu durum diğer yazın türlerin çevirisi için geçerli olsa da, örneğin anlamsız bir ifade ya da sözcü̆ü hedef metinde anlamsız olarak aktarmak tiyatroyu, absürd tiyatroyu ve çevirilerini ayrı bir yere koymaktadır. Ayrıca Ionesco'nun şu düşüncesi, tiyatro oyun metninin çeviri sürecine farklı bir bakış açısı getireceği düşünülmektedir: "Tiyatroda her şey dildir: sözcükler, jestler, nesneler, olayın kendisi çünkü her şey anlatmaya, belirtmeye yarar (1966, s.194). O halde tiyatro oyununun tüm ögelerinin bir iletişim ve sahnelenme kaygısı düşünüldüğünde, çevirisinin de yazın çevirisi alanında halen adından bahsettireceği düşünülmektedir.

Böylece "yazın çevirisi ve yorumlayıcı çeviri kuramına göre yazın türlerinin çevirilerinin incelemeleri" başlı̆̆ında öykü, roman, şiir ve tiyatro gibi yazın türlerinin çevirilerinin çeviri süreçleri Yorumlayıcı Çeviri Kuramı çerçevesinde incelenmiştir. Kendine ait özelliklerinin yanı sıra çeşitli dil özellikleri barındıran yazın türlerinin çeviri süreçlerinde çevirmenin aldığı kararlar üzerinde durulmuştur. Bunu yaparken YÇK’nın çeviri süreci aşamalarına değinilmiş ve çevirmenin hangi aşamada nasıl çeviri kararları aldığı yorumlanmaya çalışılmıştır. Bunun sonucunda, yazın türlerinin çevirilerinin nasıl ele alınması gerektiğinin ve Yorumlayıcı Çeviri Kuramının sahip olduğu çeviri süreci aşamalarıyla çeviribilimdeki yerinin altı çizilmiştir. 


\section{Sonuç}

Bu çalışmayla, kendisine özgü özellikleriyle hem dünya tarihine hem dünya yazın akım tarihine mal olmuş birçok tür barındıran yazın alanının çeviri süreçlerine dikkat çekilmiştir. Bu yapılırken, çeviribilimin diğer bilim dalları gibi özerkliğini kuramlarından ve stratejilerden aldığı vurgulanmaya çalışılmıştır. Aynı zamanda hem kuramsal hem uygulamalı çalışmalarda arka planda kaldığı düşünülen Yorumlayıcı Çeviri Kuramı ön plana çıkartılmış olup, kendine ait çeviri süreci aşamaları çevirmenlerin kararları çerçevesinde uygulamalı olarak gösterilmiştir. Bu uygulamayı oluşturan karşılaştırmalı çeviri inceleme yöntemine farklı bir bakış açısı da getirilmiştir. Alanda basit bir uygulama olarak görülse de, salt ve özellikle kuramsal karşılaştırmalı çeviri incelemelerinin önemine değinilmiştir.

Çalışmanın temelini oluşturan Yorumlayıcı Çeviri Kuramı'nın aşamalarının çeviri incelemesindeki uygulamalı yorumları diğer bir sonuç olarak ortaya çıkmaktadır. Özellikle anlama, sözcüklerden sıyırma ve yeniden ifade etme aşamaları çevirmenlerin çeviri kararı süreçleriyle ilişkilendirilmiştir. Ele alınan yazın türlerinin çeviri süreçlerine bakıldığında, hepsinin çeviri sürecinde eserin yazarının, döneminin ve dahil olduğu yazın akımının önemi vurgulanmıştır. Bu durumun aynı zamanda YÇK’nın özellikle anlama aşamasını temsil ettiği ifade edilmiştir. Daha sonra her edebi türün kendine ait dil özelliklerinin çeviri süreçlerini yönettiği, çeviri süreçlerinin merkezini de bu dil özelliklerinin oluşturması gerekliliğinin altı çizilmiştir. Bu dil özelliklerinin de, YÇK'nın hem anlama, hem sözcüklerden sıyırma hem de yeniden ifade etme aşamalarını yönlendirmesi gerekliliği belirtilmiştir.

Genel olarak öykü, roman, şiir ve tiyatro gibi yazın türlerin çeviri süreçlerine bakılacak olunursa, çevirmenlerin ilgili yazın türünün şu özelliklerine dikkat etmesi gerektiği sonucu çıkmıştır: Öykü için dar anlatım ve gözlem diline; roman için daha geniş ve tüm romana yayılan anlatım diline; şiir için en üst seviyede kullanılan dile ve birkaç sözcükle birçok şeyi anlatmaya; tiyatro için sahnelenebilecek bir metin diline ve tiyatroyu oluşturan her şeyin bir dil olduğuna. Bunların bu kadarla sinırlı olmadığı, çevirmek için ele alınan eserin kendine ait özelliklerine göre değişkenlik gösterebileceği de belirtilmiştir. $\mathrm{Bu}$ özelliklerin, çevirmenlerin YÇK'da özellikle sözcüklerinden sıyırma ve yeniden ifade etme aşamalarında önemli olduğu ve verilecek çeviri kararının uygunluğunun ve eşdeğerliğinin buna göre şekillendiği üzerinde durulmuştur.

Böylelikle, dünya çeviri piyasasının önemli bir bölümünü oluşturan yazın çevirisinin nasıl ele alınması gerektiği konusuna kuramsal bir bakış açısı getirilmiştir. Her bir yazın türü çevirisi incelemesi için belirlenen bir inceleme tablosu çerçevesinde bu yazın türlerinin genel çeviri süreçleri ele alınsa da, her bir tür üzerine ayrı ve detaylı olarak yapılacak çalışmalar yazın alanı çevirisini güçlendirecektir. Bu çalışmalar yapılırken tarihin farklı dönemlerine mal olmuş eserler seçilirse, aynı yazın türü olsa dahi farklı dil kullanımlarının ortaya çıkacağı gibi bu farklılıkların çeviri incelemeleri de alana farklı bakış açllar getirecektir. İnsanoğlu var olduğu sürece, yazın da kendine ait türlerle var olmaya devam edecektir. Bu yüzden geçmişteki ve gelecekteki eserlerin, dahil olduğu yazın türlerinin özelliklerine göre yapılacak çevirileri de değişkenlik gösterecektir. Fakat en azından bu çalışmada vurgulandığı gibi yazın çevirisinde izlenecek çeviri süreçlerinde çok fazla değişme olmayacağı ve çalışmada sıralanan özelliklerin çeviri sürecinde güncelliklerini koruyacağı düşünülmektedir. Güncelliklerini koruyacağı düşünülen yazın eserinin bu çeviri süreçlerinin çevirmenler tarafından belirli bir düzen içinde ya da daha çok belirli bir kuramın çeviri süreçlerine göre ele alınması, yazın metninin yazarının özelliklerine göre hedef dil, yazın ve kültürdeki yerini bulması açısından önemli olduğu bir kez daha bu çalışma ile ifade edilmiştir. 


\section{Kaynakça}

Aksoy, N. B. (2002). Geçmişten günümüze yazın çevirisi. Ankara: İmge.

Albir, A. H. (2005). La théorie interprétative de la traduction-sa place en traductologie. F. Israël \& M. Lederer (Ed.), La théorie interprétative de la traduction I - genèse et développement içinde (s.163-193). Paris: Lettres modernes minard.

Alkan, E. (1994). Gérar de Nerval: yaşamı-sanatı-yapttları. İstanbul: İnkılap.

Alkan, E. (2005). Şïr sanatı. İstanbul: İnkılap.

Delisle, J. (1980). L'Analyse du discours comme métohde de traduction. Ottowa: Éditions de l'Université d'Ottowa.

Delisle, J. (2005). Le sens à travers l'histoire de la traduction de l'Antiquité à la fin du XIX ${ }^{\mathrm{e}}$ siècle. F. Israël \& M. Lederer (Ed.), La théorie interprétative de la traduction II - convergences, mise en perspective içinde (s.211-228). Paris: Lettres modernes minard.

Ionesco, E. (1965). Kel şarkııı (Ü.Tamer-G. Erkal, Çev.). İstanbul: De.

Ionesco, E. (1966). Notes et contre-notes. Paris: Gallimard.

Ionesco, E. (1991). Théâtre complet. Paris: Gallimard.

Ionesco, E. (1997). Toplu oyunları 2: kel şarkıcı, ders (H. Anamur, Çev.). İstanbul: Mitos Boyut.

Laplace, C. (2005). La genèse de la théorie Interprétative de la traduction. F. Israël \& M. Lederer (Ed.), La théorie interprétative de la traduction I-genèse et développement içinde (s.21-66). Paris: Lettres modernes minard.

Lederer, M. (1994). La traduction aujourd'hui. Paris: Hachette-Livre.

Lederer, M. (2005). Défense et illustration de la théorie interprétative de la traduction.. F. Israël \& M. Lederer (Ed.), La théorie interprétative de la traduction I-genèse et développement içinde (s.92139). Paris: Lettres modernes minard.

Maupassant, G. D. (1903). Claire de lune. Paris: Librarie Paul Ollendorf.

Maupassant, G. D. (1943). Ay ışığı (S. Sevin, Çev.). Ankara: Himi.

Maupassant, G. D. (2008). Ay Işı̆̆ (T. Yücel, Çev.). İstanbul: Can.

Maupassant, G. D. (2018). Ay Işı̆̆ (H. Portakal, Çev.). İzmir: Cem.

Nerval, G. D. (1964). Les cydalises (H.K. Öztaş, Çev.). H. Kaya Öztaş (Ed.), İki dilde bir güldeste içinde (s.54-55). Ordu: Us.

Nerval, G. D. (1976). İlk sevgililer (S. Eyüboğlu-O. V. Kanık, Çev.). Magdi Rufer Eyüboğlu (Ed.), Sabahattin Eyüboğlu şiir çevirileri içinde (s.23). İstanbul: Cem.

Nerval, G. D. (1994). Nerde sevdiğimiz kızlar (E. Alkan, Çev.). Erdoğan Alkan (Ed.), Gérard de Nerval: yaşaml-sanatı-yapıtları içinde (s.188). İstanbul: Broy.

Pavis, P. (1999). Sahneleme-Kültürler kavşağında tiyatro (S. Kamber, Çev.). Ankara: Dost.

Salomon, P. (1978). Littérature française. Paris: Bordas.

Saraç, T. (2003). Fransızca-Türkçe sözlük. İstanbul: Adam.

Türk Dil Kurumu (2019). Güncel Türkçe sözlük. http://sozluk.gov.tr/ sayfasından erişilmiştir.

Vural, H. (2002). Öykü dili. Türk Dili ve Edebiyath Dergisi, C:2002/II, 607, s.225-228.

Yücel, T. (1978). Çeviride anlatı dili. Türk Dili ve Edebiyatı Dergisi, C: XXXVIII, 322, s.76-79.

Zola, E. (1969). Hayvanlaşan İnsan (H. Varoğlu, Çev.). İstanbul: Remzi.

Zola, E. (1997). La bête humaine. Paris: Fasquelle.

Zola, E. (2018). Hayvanlaşan İnsan (A. Özgüner, Çev.). İstanbul: Türkiye İş Bankası Kültür.

Zola, E. (2018). Hayvanlaşan İnsan (İ. C. Erseven, Çev.). Ankara: İmge. 